\title{
Aplikasi Pengingat Minum Obat Di Desa Sumbersuko Kecamatan Wagir Kabupaten Malang
}

\author{
ITSK dr. Soepraoen Malang \\ rudymardianto@itsk-soepraoen.ac.id
}

\begin{abstract}
The people of Sumbersuko village in Wagir sub-district, Malang district, on average, already have an Android-based smartphone. The medication reminder application found on the smartphone is not yet known and used. The training program for 12 health cadres is expected that they understand and are able to use the medication reminder application well. Training is given to health cadres so that they can disseminate information to the community. The methods used in the training were lectures, discussions and trials with smartphones by health cadres. Beginning with the introduction of medication reminder applications, techniques for downloading applications and filling in drug data. The medication reminder application is important for people who are undergoing treatment for chronic diseases such as diabetes mellitus, tuberculosis, hypertension and other diseases who must take medication uninterruptedly. Medication reminder applications can improve adherence. Compliance with taking medication is one of the factors that affect the success of treatment, so the presence of this application is appropriate when applied. The alarm in the medication reminder application will help especially the elderly in Sumbersuko village. The presence of a medication reminder application is expected to improve people's quality of life and reduce mortality and morbidity.
\end{abstract}

Keywords: Application, Compliance, Drug.

\begin{abstract}
Abstrak
Masyarakat desa Sumbersuko yang berada di kecamatan Wagir kabupaten Malang rata-rata sudah memiliki smartphone berbasis android. Aplikasi pengingat minum obat yang terdapat di smartphone belum dikenal dan digunakan. Program pelatihan kepada 12 kader kesehatan diharapkan bahwa mereka memahami dan mampu menggunakan aplikasi pengingat minum obat dengan baik. Pelatihan diberikan kepada kader kesehatan sehingga mereka dapat melakukan sosialisasi ke masyarakat. Metode yang digunakan dalam pelatihan adalah ceramah, diskusi dan uji coba dengan smartphone oleh kader kesehatan. Diawali pengenalan aplikasi pengingat minum obat, teknik mengunduh aplikasi dan pengisian data obat. Aplikasi pengingat minum obat penting bagi masyarakat yang menjalani pengobatan penyakit kronis seperti diabetes melitus, tuberculosis, hipertensi dan penyakit lain yang harus minum obat tidak terputus. Aplikasi pengingat minum obat dapat meningkatkan kepatuhan. Kepatuhan minum obat merupakan salah satu faktor yang mempengaruhi keberhasilan pengobatan maka kehadiran aplikasi ini tepat apabila diterapkan. Alarm yang terdapat di aplikasi pengingat minum obat akan membantu terutama para lansia di desa Sumbersuko. Kehadiran aplikasi pengingat minum obat diharapkan dapat
\end{abstract}


meningkatkan kualitas hidup masyarakat serta menurunkan mortalitas dan morbiditas.

Kata Kunci : Aplikasi, Kepatuhan, Obat.

\section{PENDAHULUAN}

Data Badan Pusat Statistik tahun 2019, Wagir merupakan salah satu dari 33 kecamatan di wilayah kabupaten Malang. Secara astronomis kecamatan Wagir terletak diantara 112,5406 bujur timur sampai 112,6112 bujur timur dan 8,0301 lintang selatan sampai 7,9702 lintang selatan. Letak geografi sekitar 11 desa berada di lereng dan 1 desa berada di dataran dengan topografi desa tergolong perbukitan dan dataran. Luas kawasan kecamatan Wagir secara keseluruhan adalah 75,43 km2 atau sekitar 2,53 persen dari total luas kabupaten Malang. Desa Sumbersuko merupakan bagian dari kecamatan Wagir kabupaten Malang (Badan Pusat Statistik Kota Malang, 2011).

Aplikasi pengingat minum obat untuk meningkatkan kepatuhan minum obat sehingga kualitas kesehatan masyarakat menjadi lebih baik. Akibat ketidakpatuhan minum obat adalah penggunaan obat kurang dari semestinya sehingga obat kurang efektif menyebabkan tidak ada perbaikan penyakit pada pasien. Ketidakpatuhan minum obat juga dapat terjadi penggunaan obat melebihi dari semestinya sehingga dapat menimbulkan toksisitas. (Joenoes N.Z, 2007). Aplikasi pengingat minum obat sangat penting untuk menurunkan morbiditas dan mortalitas terkait dengan kepatuhan minum obat.

Berdasarkan hasil survei diketahui permasalahan mitra yang teridentifikasi adalah:

Tabel 1

Identifikasi Permasalahan, Solusi dan Partisipasi Mitra

\begin{tabular}{|c|c|c|c|}
\hline No & Permasalahan & $\begin{array}{l}\text { Kegiatan Solusi } \\
\text { Permasalahan }\end{array}$ & $\begin{array}{l}\text { Partisipasi Mitra dalam } \\
\text { Kegiatan }\end{array}$ \\
\hline 1 & $\begin{array}{l}\text { Kepatuhan minum } \\
\text { obat pada kader sedang } \\
58 \% \text { yang digunakan } \\
\text { sebagai indikator } \\
\text { untuk kepatuhan } \\
\text { masyarakat. }\end{array}$ & $\begin{array}{l}\text { Sosialisasi aplikasi } \\
\text { pengingat minum } \\
\text { obat kepada kader } \\
\text { kesehatan desa } \\
\text { sumbersuko. }\end{array}$ & $\begin{array}{l}\text { 1. Menyiapkan sarana } \\
\text { dan prasarana } \\
\text { kegiatan pelatihan } \\
\text { penggunaan aplikasi } \\
\text { minum obat. } \\
\text { 2. Mengundang kader } \\
\text { kesehatan desa } \\
\text { Sumbersuko. }\end{array}$ \\
\hline 2 & $\begin{array}{l}\text { Rendahnya } \\
\text { pengetahuan } \\
\text { masyarakat terhadap } \\
\text { aplikasi pengingat } \\
\text { minum obat berbasis } \\
\text { smartphone. }\end{array}$ & $\begin{array}{l}\text { Pelatihan dan } \\
\text { pendampingan } \\
\text { aplikasi pengingat } \\
\text { minum obat kepada } \\
\text { kader kesehatan untuk } \\
\text { disosialisasikan ke } \\
\text { masyarakat desa } \\
\text { Sumbersuko. }\end{array}$ & $\begin{array}{l}\text { Memantau selama } \\
\text { kegiatan berlangsung. }\end{array}$ \\
\hline
\end{tabular}


Lama pemakaian obat bervariasi ketika seseorang sakit dan menjalani pengobatan. Keberhasilan pengobatan seseorang tidak hanya ditentukan oleh kesesuaian obat tetapi kepatuhan menggunakan obat juga. Ketidakpatuhan sendiri dipengaruhi beberapa faktor seperti ketidaksesuaian dengan instruksi yang tertulis pada etiket obat, duplikasi minum obat, lupa minum obat dan minum obat tidak sesuai interval yang seharusnya (Joenoes N.Z, 2007). Seseorang yang menjalani pengobatan akibat penyakit kronis misalnya hipertensi, diabetes melitus, tuberculosis akan menerima obat dengan jangka waktu lama dan jumlah obat yang bervariasi sehingga membutuhkan alat bantu untuk mengingatkan waktu yang tepat minum obat.

Smartphone merupakan alat komunikasi dan sumber informasi yang mudah diakses. Smartphone menjadi kebutuhan masyarakat karena efisiensi waktu, tenaga dan biaya. Ratusan aplikasi ada di pasar memiliki kualitas, konten, dan fungsionalitasnya bervariasi (Bailey et al., 2014). Sejumlah besar aplikasi kepatuhan minum obat yang terdapat di smartphone saat ini tersedia. Sebagian besar aplikasi memiliki fitur yang mewakili pendekatan perilaku untuk intervensi. Temuan analisis konten menawarkan sebagian besar umpan balik positif serta wawasan tentang keterbatasan dan peningkatan yang dapat diatasi dalam aplikasi kepatuhan pengobatan saat ini dan masa depan (Park et al., 2019). Data hasil penelitian tentang penggunaan aplikasi di smartphone menunjukkan bahwa peringkat pertama yang banyak digunakan adalah pengingat minum obat (pill reminder) (Tabi et al., 2019).

Tujuan sosialisasi dan pelatihan aplikasi pengingat minum obat adalah meningkatkan kepatuhan. Sosialisasi dan pelatihan diberikan kepada kader kesehatan karena mereka berperan penting dalam penyebaran informasi ke masyarakat. Hasil pretest terhadap kader kesehatan menunjukkan angka kepatuhan sedang 58\%. Para kader kesehatan mewakili kelompok masyarakat yang ada di desa Sumbersuko. Tes ini dilakukan sebagai penjajakan sebelum melakukan sosialisasi dan pelatihan aplikasi pengingat minum obat kepada kader kesehatan. Luaran yang diharapkan setelah dilakukan sosialisasi dan pelatihan adalah terjadi peningkatan kepatuhan minum obat.

\section{METODE}

Sasaran pelatihan aplikasi pengingat minum obat adalah masyarakat yang memiliki kemampuan terbatas. Alasan pemilihan kader kesehatan adalah mereka merupakan ujung tombak sosialisasi hasil pelatihan ke masyarakat. Kegiatan dilaksanakan di balai desa yang dihadiri 12 kader kesehatan. Di Masa pandemi COVID-19 pelaksanaan tetap mengikuti protokol kesehatan sehingga jumlah kader kesehatan yang mengikuti pelatihan dibatasi sesuai kapasitas ruangan. Kader kesehatan telah ditentukan oleh kepala desa Sumbersuko berkoordinasi dengan tim pengabdian masyarakat. Tim pengabdian masyarakat terdiri dari dosen dan mahasiswa. 


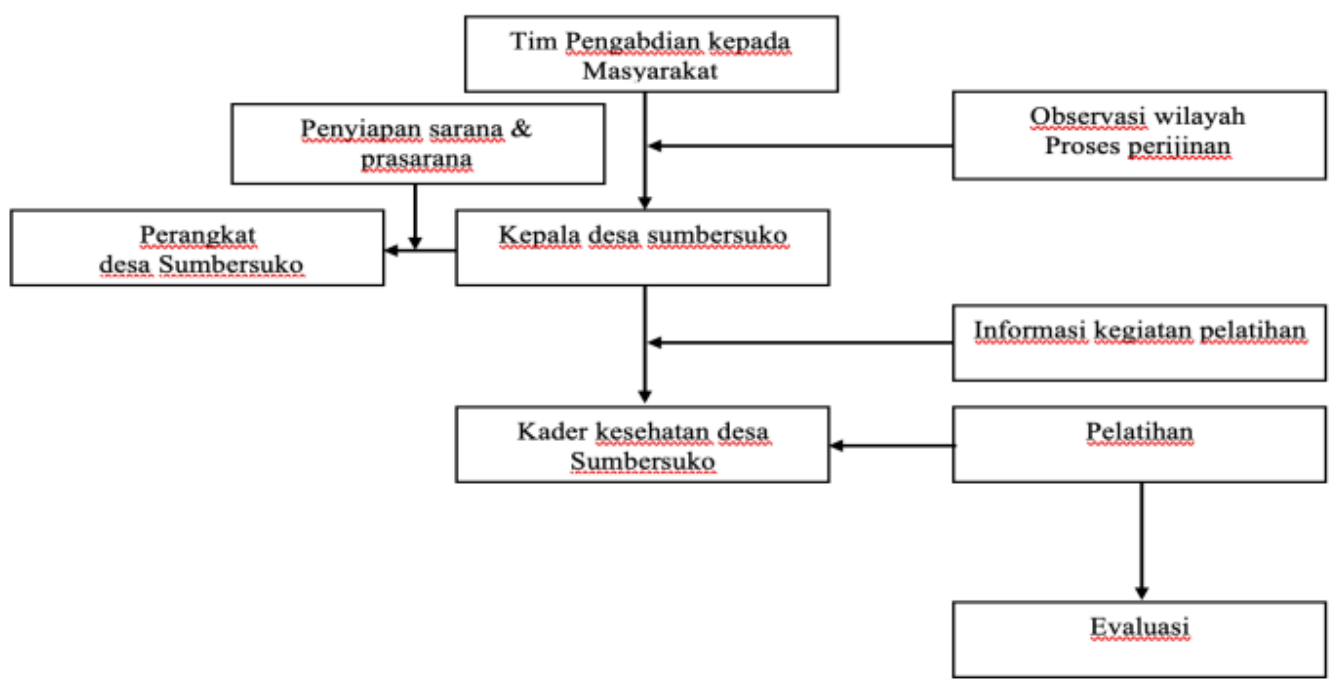

Gambar 1: Rancangan Kegiatan

Sarana dan prasarana yang digunakan saat kegiatan

1. Kursi peserta

2. Lembar kuesioner

3. LCD proyektor

4. Laptop

5. Pointer

6. Pengeras suara

Langkah-langkah kegiatan pada pelatihan aplikasi pengingat minum obat adalah sebagai berikut:

1. Kegiatan pelatihan diawali dengan membagikan kuesioner kepatuhan minum obat kepada kader kesehatan.

2. Sosialisasi pentingnya kepatuhan minum obat untuk menunjang keberhasilan pengobatan.

3. Pengenalan aplikasi pengingat minum obat untuk meningkatkan kepatuhan. Teknik mendapatkan aplikasi di smartphone berbasis offline sehingga tidak tergantung jaringan internet.

4. Teknik mengunduh aplikasi pengingat minum obat didampingi oleh tim pengabdian kepada masyarakat.

5. Teknik pengisian data nama obat, aturan pakai, penentuan waktu tepat minum obat dan pengisian tanggal berakhir obat utnuk diminum.

6. Penerapan instruksi yang telah diberikan kepada para kader kesehatan. 


\section{HASIL DAN PEMBAHASAN}

\section{Hasil}

Tabel 2

Hasil Pengukuran Kepatuhan Minum Obat Kader Kesehatan Desa Sumbersuko.

\begin{tabular}{lccc}
\hline Kategori & Skor & Jumlah & Persentase (\%) \\
\hline Rendah & $0-<6$ & 2 & 17 \\
\hline Sedang & $6-8$ & 7 & 58 \\
\hline Tinggi & $<8$ & 3 & 25 \\
\hline Total & & $\mathbf{1 2}$ & $\mathbf{1 0 0}$ \\
\hline
\end{tabular}

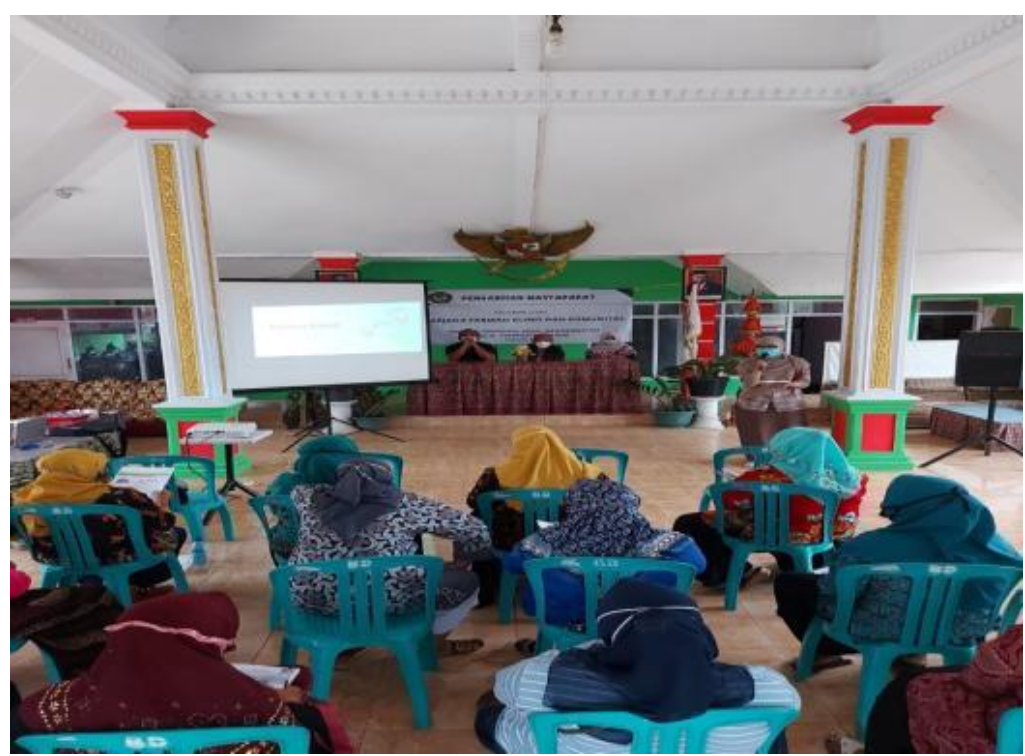

Gambar 1. Pembukaan pelatihan pengenalan aplikasi pengingat minum obat desa Sumbersuko. 




Gambar 2. Pelaksanaan pengenalan aplikasi pengingat minum obat desa Sumbersuko.

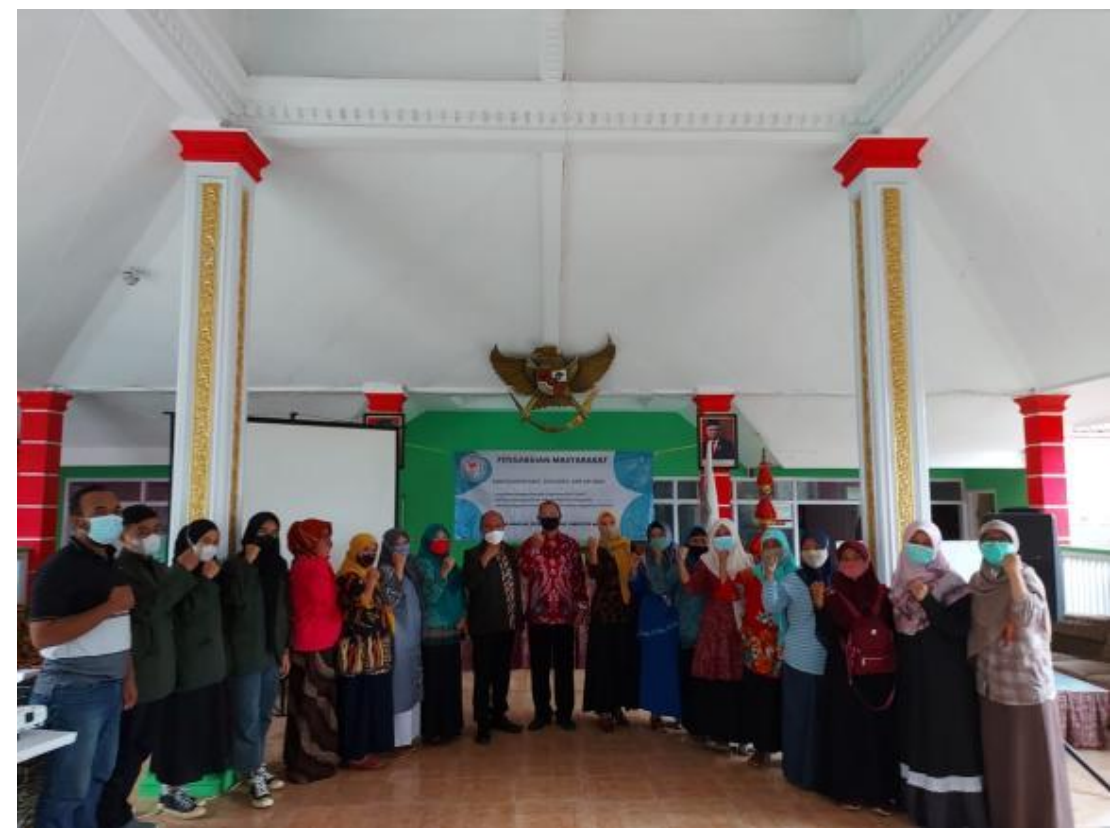

Gambar 3. Dokumentasi berakhirnya kegiatan pelatihan penggunaan aplikasi pengingat minum obat. 




Gambar 4. Aplikasi pengingat minum obat.



Gambar 5. Pengisian data obat, jadwal dan alarm di aplikasi pengingat minum obat

\section{Pembahasan}

Hasil pengukuran kepatuhan minum obat menunjukkan bahwa kriteria rendah $17 \%$, sedang $58 \%$ dan tinggi 25\%. Bila dilihat dari hasil pengukuran kepatuhan minum obat maka masih perlu untuk ditingkatkan. Salah satu faktor yang mempengaruhi kepatuhan adalah "lupa" ketika harus minum obat. Aplikasi pengingat minum obat akan membantu saat yang tepat minum obat. Aplikasi ini berbasis alarm yang akan berbunyi saat harus minum obat dan menampilkan nama obat yang harus diminum. Data hasil penelitian yang pernah dilakukan oleh Reddy et al., tentang penggunaan alarm pada pasien yang 
menerima obat jantung menunjukkan bahwa alarm meningkatkan kepatuhan obat statin, relatif mudah diterapkan dan biaya rendah (Reddy et al., 2017).

Penelitian yang berbeda terkait kepatuhan minum obat antihipertensi menunjukkan bahwa terdapat hubungan antara kepatuhan minum obat dengan jumlah obat yang diterima. Ketika obat yang diterima 9 atau lebih maka tanpa memandang usia kepatuhan akan menurun (Kim et al., 2019). Pentingnya aplikasi pengingat minum obat akan memudahkan pasien untuk mengingatkan obat mana yang harus diminum.

Ketika pelatihan, kader kesehatan didampingi oleh tim pengabdian masyarakat. Pendampingan bertujuan untuk membantu kader kesehatan pada saat mengunduh aplikasi dan pengisian data obat yang harus diminum. Tim pengabdian menggunakan aplikasi yang terdapat di google play store. Ketika dilakukan pendampingan terasa masih asing dan terkendala jaringan internet. Pengisian data obat juga kesulitan karena menggunakan nama latin yang tidak umum, tetapi bisa dicontoh pada blister obat yang ada. Penulisan aturan pakai menyesuaikan dengan etiket obat yang diterima. Pengaturan waktu masih terdapat kendala karena menggunakan sistem yang tidak baku dalam bahasa Indonesia. Diharapkan terdapat penyempurnaan aplikasi yang lebih mudah dipahami bagi masyarakat yang memiliki karakteristik bervariasi, usia, pekerjaan tingkat pendidikan. Ketika selesai pelatihan peggunaan aplikasi pengingat minum obat maka dilanjutkan dengan tanya jawab. Evaluasi yang dilakukan tim pengabdian menunjukkan sikap antusias dan berharap kegiatan serupa dapat dilakukan kembali.

\section{KESIMPULAN}

Aplikasi pengingat minum obat berbasis offline yang terdapat di smartphone android dapat dipahami dan diterapkan dengan baik oleh kader kesehatan Sumbersuko kecamatan Wagir kabupaten Malang.

\section{Saran}

1. Perlu dilakukan sosialisasi dan penggunaan aplikasi pengingat minum obat yang lebih sederhana dan dilakukan oleh masyarakat.

2. Perlu dilakukan sosialisasi dan implementasi aplikasi pengingat minum obat pada masyarakat dengan kelompok penyakit yang spesifik seperti kelompok penyakit diabetes melitus, hipertensi dan lainnya.

\section{DAFTAR PUSTAKA}

Badan Pusat Statistik Kota Malang. (2011). Malang Dalam Angka 2011. 1-244.

Bailey, S. C., Belter, L. T., Pandit, A. U., Carpenter, D. M., Carlos, E., \& Wolf, M. S. (2014). The availability, functionality, and quality of mobile applications supporting medication selfmanagement. Journal of the American Medical Informatics Association, 21(3), 542-546. https://doi.org/10.1136/amiajnl-2013-002232

Joenoes N.Z. (2007). Ars Prescribendi (3rd ed.). Surabaya: Airlangga University Press.

Kim, S. J., Kwon, O. D., Han, E. B., Lee, C. M., Oh, S. W., Joh, H. K., ... Choi, H. C. (2019). Impact of number of medications and age on adherence to antihypertensive medications: A nationwide $\begin{array}{lllll}\text { population-based } \quad \text { study. } & \text { Medicine }\end{array}$ https://doi.org/10.1097/MD.0000000000017825 
Park, J. Y. E., Li, J., Howren, A., Tsao, N. W., \& de Vera, M. (2019). Mobile phone apps targeting medication adherence: Quality assessment and content analysis of user reviews. JMIR MHealth and UHealth, 7(1), 1-12. https://doi.org/10.2196/11919

Reddy, A., Huseman, T. L., Canamucio, A., Marcus, S. C., Asch, D. A., Volpp, K., \& Long, J. A. (2017). Patient and Partner Feedback Reports to Improve Statin Medication Adherence: A Randomized Control Trial. Journal of General Internal Medicine, 32(3), 256-261. https://doi.org/10.1007/s11606-016-3858-0

Tabi, K., Randhawa, A. S., Choi, F., Mithani, Z., Albers, F., Schnieder, M., ... Krausz, M. (2019). Mobile apps for medication management: Review and analysis. JMIR MHealth and UHealth, 7(9). https://doi.org/10.2196/13608 